\title{
Comparison of Rational Formula Alternatives for Streamflow Generation for Small Ungauged Catchments
}

\author{
W.M.D.Wijesinghe and N.T.S.Wijesekera
}

\begin{abstract}
A Unit Hydrograph can be derived using the peak discharge obtained from the Rational Equation and using unit depth of rainfall in calculating the Rainfall Intensity. Possible alternatives for selection of sub catchments, selection of a guideline to determine the Runoff Coefficients and the Time of Concentration were taken into account. A significant variation of the results was observed with the selected alternatives. In order to select a better alternative comparison of generated streamflows with the observed values is required. Unit hydrograph derivation using the Rational method would yield a lesser peak flow value and a higher time to peak when spatially distributed approach using sub catchments is used instead of a lumped single catchment The guideline used for determination of Runoff coefficients plays very important role in Rational Method and it showed considerable variation of the results in Welipenna River Basin. The time of concentration estimation method is also important when the catchments become larger. In the Welipenna River Basin the Lumped Parameter method of deriving Unit Hydrograph taking Runoff Coefficient from based on Slope, Land Use and Soil Type with $T_{c}$ from ID Guidelines a $Q_{p}$ estimate of $0.49 \mathrm{~m}^{3} / \mathrm{s}$, while the peakflow estimate computed with the distributed parameter method using sub catchments was $0.51 \mathrm{~m}^{3} / \mathrm{s}$.
\end{abstract}

Keywords: $\quad$ Rational Equation, Runoff Coefficients, Time of Concentration

\section{Introduction}

Majority of the Infrastructure development projects in Sri Lanka often require engineers to work in ungauged catchments. When it is needed to carry out flow estimations for such ungauged catchments, the common method is to determine streamflows using Synthetic means. In the absence of flow data there are many methods for the development of Synthetic Unit Hydrograph (UH).

Rational Method is a popular method for estimating peakflows. Once the Rational Method computes the peak discharge from a particular watershed, the Direct Runoff Hydrograph (DRH) computations can be carried out using Ponrajah, 1984 [1]. In these calculations, Rainfall Intensity is required for computing peak discharge. This DRH becomes $\mathrm{UH}$ when a unit depth of rainfall is used for the determination of the rainfall intensity.

This UH from Rational Method defers due to the methods used. There are several methods to compute the Time of Concentration $\left(T_{c}\right)$ and there are many ways to delineate the sub watersheds.
Wijesekera, 2000 [2] applied Rational method for nineteen watershed that contribute to Colombo Harbour for computing peak flows. In that study comparison of runoff coefficients computed based on tabulated values from handbooks, sample areas and remote sensing data had resulted in a common coefficient value in the case of Colombo Harbour.

Batuwitage, Manchanayake and Wickramasuriya, 1986 [3] also applied Rational Equation for 16 catchments in order to calculate peak discharge. In that study they have also used the Method Recommended by Ponrajah, 1984 [1], Kirpich Equation and Bransby-William Equation, for computing Time of Concentration. In the said study it has been generally observed that the estimated values for the design flood taking the time of concentration from the Kirpich Equation and Bransby-William Equation are high when

W.M.D.Wijesinghe, B.Sc. Eng. (Moratuwa), Research Assistant, Department of Civil Engineering, University of Moratuwa, Sri Lanka

Eng. (Prof.) N.T.S.Wijesekera, B.Sc. Eng. (Sri Lanka), C. Eng., FIE(Sri Lanka), M. Eng. (Tokyo), D. Eng. (Tokyo), Senior Professor of Civil Engineering, Department of Civil Engineering, University of Moratuwa, Sri Lanka 
compared to the values from Statistical Methods. In the same study the Kirpich equation was found to give lower values for the time of concentration than the Bransby-William Equation for all the catchments and hence the former gives higher rainfall intensity and consequently higher flood peak. A noteworthy feature observed in the study was that the estimated flood peaks are comparable to those obtained using statistical methods. Discrepancies between the results obtained from the two methods are less for smaller catchments than for larger catchments. For the smaller catchments the agreement between the two sets of results may be due to the fact that Ponrajah, 1984 [1] recommends the use of velocity estimates based on slope, for determining the time of concentration. In that paper it is recommended that one should note that the method of Ponrajah, 1984 [1] and the Rational Method in general are intended for smaller catchment areas less than about $25 \mathrm{~km}^{2}$. In the study it has been seen that the method used for the determination of time of concentration is vital and has very considerable effect on the design flood estimate.

In design flood estimation the approach is to develop Unit Hydrograph (UH) for the considered watershed and then use for the generation of streamflows for a considered design return period.

\section{Objective}

The present study focuses on applying the Rational Formula for a small watershed to check the variations that would occur due to various alternative ways of application.

The specific objectives of the study are to assess

- The options for governing equations

- The alternatives for selecting parameters

- The alternatives for selecting sub catchments

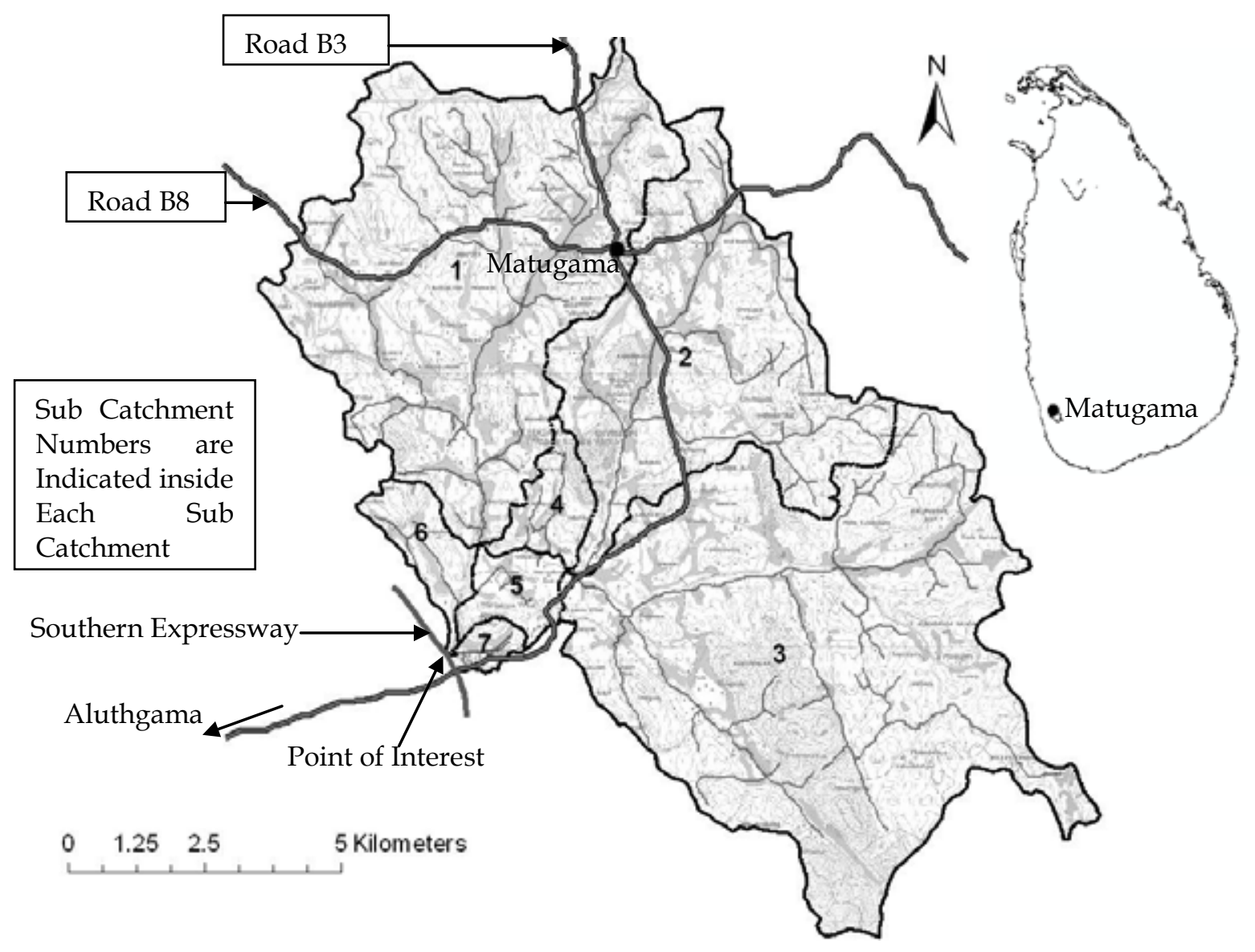

Figure 1 - Study Area and Associated Sub Catchments 


\section{Study Area}

The study was carried out for the watershed of Welipenna Ganga, which is a tributary of Bentota Ganga, at its intersection point with the Southern Expressway near the Welipenna Interchange of the said Expressway, which has a drainage area of $121 \mathrm{~km}^{2}$. This watershed is an ungauged watershed which causes flooding at the intersection after the construction of a drainage structure. As part of the effort to find solutions for flooding, the investigation of peakflow estimation at this catchment was undertaken. The catchment is in a rural setting with land uses of paddy, forest, scrubs and commercial cultivations of rubber, tea and coconut with smaller urban area. There are no reservoirs or other significant water storages within the basin or water diversions from or into the watershed. Field visits were undertaken to observe the watershed and its drainage characteristics. 1:10,000 topographic maps of the Survey Department of Sri Lanka were used for calculation of catchment parameters.

The watershed could be divided into seven sub catchments, considering the major tributaries of and the main watercourse (Figure 1). Parameters required for the calculations extracted from the main watershed and each sub watershed are presented in Table 1. Catchment slopes were determined considering the elevation difference of the highest and lowest points of the longest stream, $H$ of each sub catchment.

\section{Methodology}

\subsection{Approach}

In this approach it is assumed that the peak discharge is observed after $T_{c}$ duration, where $T_{c}$ is the time of concentration for the watershed and in computing peak discharge the rainfall intensity is assumed to be constant within $T_{c}$ duration. Since the Unit Hydrograph (UH) is derived for a unit depth of rainfall over certain duration the rainfall intensity was calculated assuming one inch rainfall over $T_{c}$ duration. A curvilinear UH was obtained for each case using the dimensionless coefficients given in Irrigation Department (ID) Guidelines [4] and the co-ordinates of the Unit Hydrographs were then modified so that the area under the curve is unity.
The main parameters required to determine the UH for a particular watershed are, Runoff Coefficients (RC), $T_{c}$ and the area of the watershed.

\subsection{Alternatives for Selecting Runoff Coefficients}

$\mathrm{RC}$ computations were determined using three guidelines. Runoff coefficients were calculated based on

Guideline 1 slope [1]

Guideline 2 Land Use [5]

Guideline 3 Slope, Land Use and Hydrologic Soil Type [6].

\subsection{Options for Governing Equations}

The equations in references were used to calculate the time of concentration.

Irrigation Department (ID) Guidelines [1], $T_{c}=L /(60 \mathrm{~V})+15$

Where $L=$ Longest stream length (feet) $V=$ Flow Velocity obtained

from ID Guidelines (feet/s)

Kirpich Equation [5]

$T_{c}=0.0078 L^{0.77} S^{-0.385}$

Where $L=$ Longest stream length (feet) $S=$ Watershed Slope (feet $/$ feet $)$

Bransby-William (B-W) Formula [7].

$$
\begin{aligned}
& T_{c}=\frac{58.5 L}{A^{0.1 S^{0.2}}} \\
& \text { Where } L=\text { Longest stream length }(\mathrm{km}) \\
& S=\text { Watershed Slope }(\mathrm{m} / \mathrm{km}) \\
& A=\text { Watershed Area }\left(\mathrm{km}^{2}\right)
\end{aligned}
$$

\subsection{Spatial Variation of Sub Catchments}

For the comparative assessment, three cases were considered.

Case 1 Peakflow estimations were made considering the entire drainage area for the considered location as a single lumped unit.

Case 2 The peakflow computations for each sub-catchment was carried out considering that the sub watershed outlet is the point at which a sub-watershed would drain to the main stream while assuming that flow taking place along the mainstream subsequent to the joining, would not have any effect on the estimations.

Case 3 Peakflow estimations were carried out considering that runoff generation of a particular watershed would be limited to the drainage area determined by the point at which the sub-watershed joins the main stream but 
time of concentration depends on the stream length within the sub-watershed added to the main-stream length after the point of entry and the outlet of main watershed.

\section{Data}

Land Use types and their percentages were extracted from 1:50,000 maps. As per the
General Soil Map for Sri Lanka [8] the soil type found within the catchment is Red Yellow Podzolic Soil. From the soil description given in the map it is reasonable to assume the Hydrologic soil type to be of Group B.

Table 1 - Details of Main Catchment and Sub Catchments

\begin{tabular}{|c|c|c|c|c|c|c|c|}
\hline \multirow{2}{*}{$\begin{array}{c}\text { Main/Sub } \\
\text { Catchment }\end{array}$} & \multirow{2}{*}{$\begin{array}{c}\text { Area } \\
\left(\mathrm{km}^{2}\right)\end{array}$} & $\begin{array}{c}\text { Longest Stream } \\
\text { Length, } L(\mathrm{~km})\end{array}$ & \multicolumn{2}{c|}{$\begin{array}{c}\text { Elevation } \\
\text { Difference, } H(\mathrm{~m})\end{array}$} & \multicolumn{3}{c|}{ Slope (\%) } \\
\cline { 5 - 9 } & Case 1/2 & Case 3 & Case 1/2 & Case 3 & Case 1/2 & Case 3 \\
\hline Main & 122.0 & 18.1 & 18.1 & 150.1 & 150.1 & 0.829 & 0.829 \\
\hline Sub Catchment 1 & 38.8 & 11.0 & 13.6 & 157.8 & 158.1 & 1.435 & 1.164 \\
\hline Sub Catchment 2 & 25.2 & 8.7 & 13.3 & 136.2 & 138.1 & 1.565 & 1.038 \\
\hline Sub Catchment 3 & 49.4 & 13.5 & 18.1 & 148.2 & 150.1 & 1.097 & 0.829 \\
\hline Sub Catchment 4 & 2.6 & 2.2 & 6.3 & 7.2 & 6.5 & 0.267 & 0.104 \\
\hline Sub Catchment 5 & 2.4 & 1.6 & 3.2 & 5.2 & 5.9 & 0.323 & 0.182 \\
\hline Sub Catchment 6 & 2.8 & 2.6 & 3.8 & 5.2 & 5.6 & 0.201 & 0.147 \\
\hline Sub Catchment 7 & 0.9 & 1.2 & 1.4 & 2.2 & 3.0 & 0.189 & 0.212 \\
\hline
\end{tabular}

Table 2 - Land Use Areas in Each Catchment in $\mathbf{k m}^{2}$

\begin{tabular}{|c|c|c|c|c|c|}
\hline & 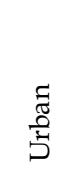 & $\frac{\overrightarrow{0}}{\frac{0}{0}}$ & $\begin{array}{l}\dot{D} \\
\stackrel{D}{0} \\
\text { II }\end{array}$ & 疋 & 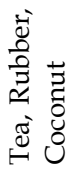 \\
\hline Entire Catchment & 4 & 3.99 & 14.25 & 9.79 & 7.04 \\
\hline Sub Catchment 1 & 2.03 & 6.05 & 0.99 & 0.19 & 29.24 \\
\hline Sub Catchment 2 & 1.96 & 3.43 & 1.95 & 0.3 & 17.57 \\
\hline Sub Catchment 3 & 0 & 3.33 & 6.61 & 6.08 & 31.02 \\
\hline Sub Catchment 4 & 0 & 0.53 & 0.23 & 0.31 & 1.45 \\
\hline Sub Catchment 5 & 0 & 0.27 & 0 & 0 & 2.13 \\
\hline Sub Catchment 6 & 0 & 0.63 & 0 & 0.15 & 1.7 \\
\hline Sub Catchment 7 & 0 & 0.63 & 0 & 0.15 & 1.7 \\
\hline
\end{tabular}

Table 3 - Runoff Coefficients Calculated Using Three Alternatives

\begin{tabular}{|l|r|r|r|}
\hline $\begin{array}{l}\text { Main/Sub } \\
\text { Catchment }\end{array}$ & Slope & \multicolumn{1}{l|}{$\begin{array}{l}\text { Land } \\
\text { Use }\end{array}$} & \multicolumn{1}{l|}{$\begin{array}{l}\text { Slope, } \\
\text { Land } \\
\text { Use, Soil }\end{array}$} \\
\hline Main & 0.3 & 0.19 & 0.16 \\
\hline Sub Catchment 1 & 0.30 & 0.22 & 0.16 \\
\hline Sub Catchment 2 & 0.30 & 0.23 & 0.16 \\
\hline Sub Catchment 3 & 0.30 & 0.17 & 0.16 \\
\hline Sub Catchment 4 & 0.30 & 0.18 & 0.16 \\
\hline Sub Catchment 5 & 0.30 & 0.20 & 0.16 \\
\hline Sub Catchment 6 & 0.30 & 0.19 & 0.16 \\
\hline Sub Catchment 7 & 0.30 & 0.19 & 0.16 \\
\hline
\end{tabular}

\section{Results}

Table 4 shows the results from the $T_{c}$ calculations for the main watershed and sub watersheds for the three equations used. Figure 2 indicates a plot of peak discharges versus time to peak of the $\mathrm{UH}$ from each option of selecting $\mathrm{RC}$ and $T_{c}$. Figure 3 gives the UH from the options of sub watershed delineation. Results from all the computations are summarised in Table 5.

Table 4 - Time of Concentration Calculated Using Three Methods in Hours for Each Catchment

\begin{tabular}{|l|r|r|r|}
\hline $\begin{array}{l}\text { Main/Sub } \\
\text { Catchment }\end{array}$ & \multicolumn{1}{|c|}{ ID } & Kirpich & \multicolumn{1}{|c|}{ B-W } \\
\hline Main & \multicolumn{1}{|c|}{11.3} & 3.9 & 7.2 \\
\hline Sub Catchment 1 & 6.9 & 2.1 & 4.4 \\
\hline Sub Catchment 2 & 5.5 & 1.7 & 3.5 \\
\hline Sub Catchment 3 & 8.5 & 2.8 & 5.5 \\
\hline Sub Catchment 4 & 1.6 & 1.1 & 1.6 \\
\hline Sub Catchment 5 & 1.2 & 0.9 & 1.1 \\
\hline Sub Catchment 6 & 1.8 & 1.5 & 2.0 \\
\hline Sub Catchment 7 & 1.0 & 0.8 & 1.0 \\
\hline
\end{tabular}




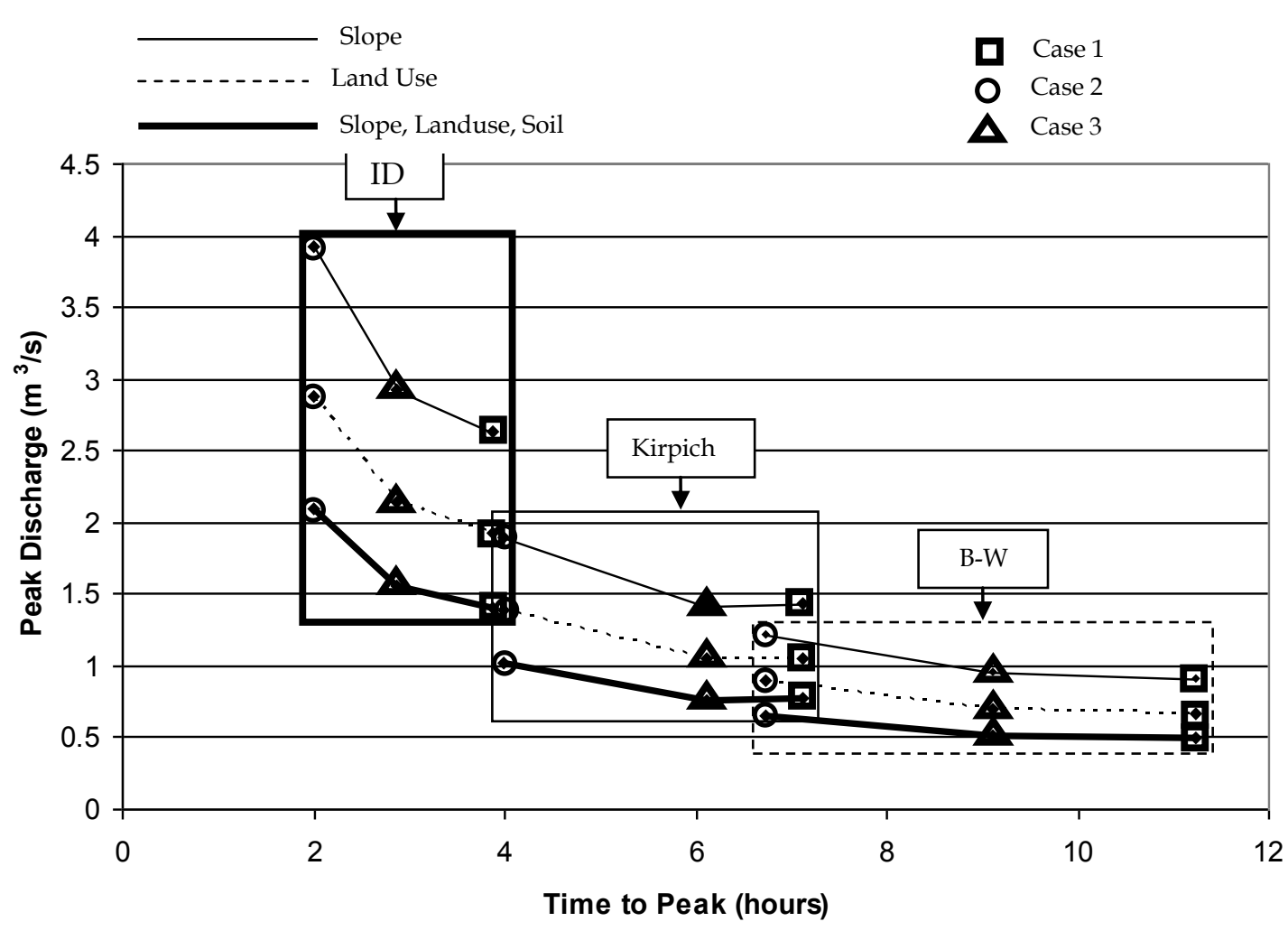

Figure 2 - Results of Peakflow and Corresponding Time to Peak with Variation of Runoff Coefficient, $T_{c}$ estimation method and Method of Watershed Delineation

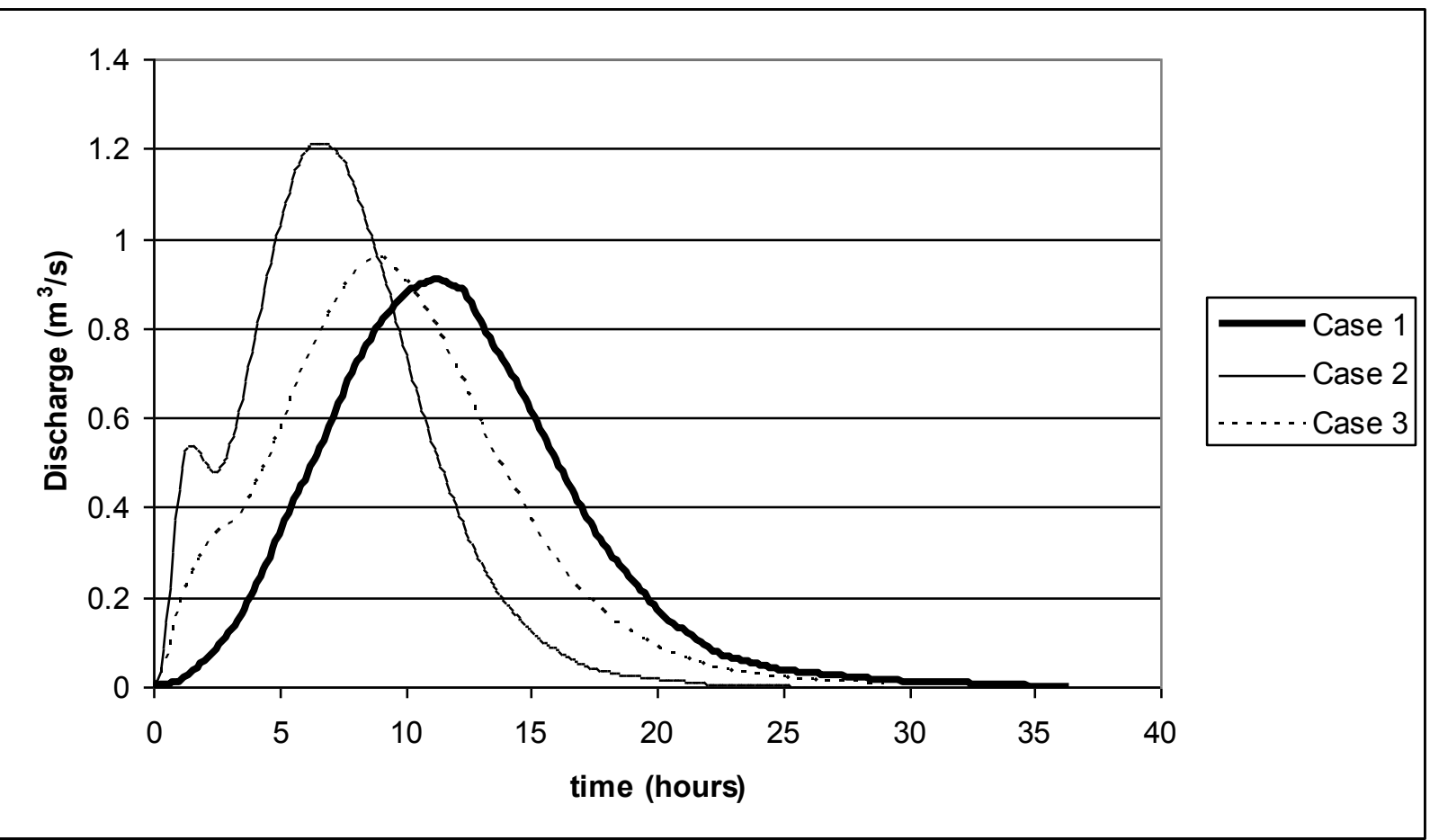

Figure 3 - UH for Different Watershed Delineation Options 
Table 5 - Summary of Peak Discharges and Times to Peaks

\begin{tabular}{|c|c|c|c|c|c|c|c|c|c|c|c|c|}
\hline & \multicolumn{3}{|c|}{$\begin{array}{c}Q_{p} \text { in } \mathrm{m}^{3} / \mathrm{s} \text { with } T_{c} \\
\text { from ID }\end{array}$} & \multirow[b]{2}{*}{ 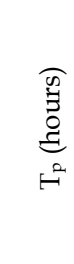 } & \multicolumn{3}{|c|}{$\begin{array}{c}Q_{p} \text { in } \mathrm{m}^{3} / \mathrm{s} \text { with } T_{c} \text { from } \\
\text { Kirpich }\end{array}$} & \multirow[b]{2}{*}{ 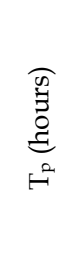 } & \multicolumn{3}{|c|}{$\begin{array}{c}Q_{p} \text { in } \mathrm{m}^{3} / \mathrm{s} \text { with } T_{c} \text { from } \\
\text { B-W Formula }\end{array}$} & \multirow[b]{2}{*}{ 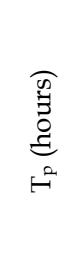 } \\
\hline & $\frac{\tilde{a}}{\tilde{\sigma}}$ & 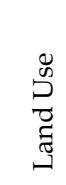 & 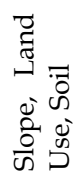 & & $\frac{\tilde{0}}{\omega}$ & 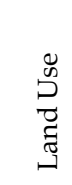 & 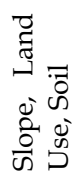 & & $\frac{\check{\partial}}{\text { के }}$ & 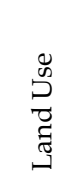 & 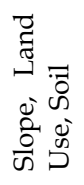 & \\
\hline Case 1 & 0.91 & 0.67 & 0.49 & 11.25 & 2.62 & 1.92 & 1.40 & 3.88 & 1.43 & 1.05 & 0.76 & 7.13 \\
\hline Case 2 & 1.21 & 0.89 & 0.65 & 6.75 & 3.92 & 2.87 & 2.09 & 2.00 & 1.90 & 1.39 & 1.01 & 4.00 \\
\hline Case 3 & 0.95 & 0.70 & 0.51 & 9.13 & 2.91 & 2.13 & 1.55 & 2.88 & 1.42 & 1.04 & 0.76 & 6.13 \\
\hline
\end{tabular}

\section{Discussion}

\subsection{Runoff Coefficients}

Runoff Coefficients based on Guideline 1 (Slope) always gave higher values resulting higher peak discharges. This is because the peak discharge was calculated using Rational Equation and in that equation the peak discharge is directly proportional to the Runoff Coefficient, when the other parameters are kept constant. Guideline 3 (Slope, Land Use and Soil Type) for selecting Runoff Coefficients can be considered as the most accurate one compared to the other two guidelines, since it uses three criteria for determining runoff coefficients. Therefore the peak values obtained from the other two methods were compared with the results from Guideline 3.

Table 6 - Percentage Variation of the Peakflows from Guideline 1 and 2 Compared to the Results from Guideline 3

\begin{tabular}{|l|l|r|r|}
\hline $\begin{array}{l}T_{c} \\
\text { Computation } \\
\text { Method }\end{array}$ & $\begin{array}{l}\text { Catchment } \\
\text { Delineation } \\
\text { Method }\end{array}$ & $\begin{array}{c}\text { Guideline } \\
1\end{array}$ & $\begin{array}{c}\text { Guideline } \\
2\end{array}$ \\
\hline \multirow{4}{*}{$\begin{array}{l}\text { ID } \\
\text { Guidelines }\end{array}$} & Case 1 & 85.71 & 36.73 \\
\cline { 2 - 4 } & Case 2 & 86.15 & 36.92 \\
\cline { 2 - 4 } & Case 3 & 86.27 & 37.25 \\
\hline \multirow{4}{*}{$\begin{array}{l}\text { Kirpich } \\
\text { Equation }\end{array}$} & Case 1 & 703.57 & 37.14 \\
\hline \multirow{4}{*}{$\begin{array}{l}\text { B-W } \\
\text { Equation }\end{array}$} & Case 2 & 222.97 & 37.32 \\
\cline { 2 - 4 } & Case 3 & 489.03 & 37.42 \\
\cline { 2 - 4 } & Case 1 & 410.53 & 38.16 \\
\cline { 2 - 4 } & Case 2 & 98.02 & 37.62 \\
\hline \multirow{2}{*}{} & Case 3 & 278.95 & 36.84 \\
\hline
\end{tabular}

7.2 Time of Concentration and Time to Peak

Theoretically both Time to Peak and Peak Discharge are influenced by Time of Concentration since it is used in both peakflow estimation and determination of time to peak. (Figure 2). From Figure 2 it is noticed that there is a vital effect from the method used to estimate Time of Concentration to Peak Discharge and Time to Peak. The $T_{c}$ values for the main catchment and each sub catchment from the three methods are presented in Table 5.

Kirpich Equation resulted in the lowest values of $T_{c}$ while ID guidelines resulted in the highest values of $T_{c}$. The values calculated using Kirpich equation were used as base values for the determination of the percentage variation of the values from the other two equations.

Table 7 - Percentage Difference of $T_{c}$ from ID and B-W Equations Compared to $T_{c}$ from Kirpich Equation

\begin{tabular}{|c|c|c|c|}
\hline \multirow{2}{*}{$\begin{array}{l}\text { Main/Sub } \\
\text { Catchment }\end{array}$} & \multirow[t]{2}{*}{$\begin{array}{l}\text { Catchment } \\
\text { Area }\left(\mathrm{m}^{2}\right)\end{array}$} & \multicolumn{2}{|c|}{$\begin{array}{c}\text { \% Difference } \\
\text { of } T_{c} \text { with } \\
\text { Kirpich } \\
\text { Equation }\end{array}$} \\
\hline & & ID & B-W \\
\hline Main & 122.0 & 189.7 & 84.6 \\
\hline Sub 1 & 38.8 & 228.6 & 109.5 \\
\hline Sub 2 & 25.2 & 223.5 & 105.9 \\
\hline Sub 3 & 49.4 & 203.6 & 96.4 \\
\hline Sub 4 & 2.6 & 45.5 & 45.5 \\
\hline Sub 5 & 2.4 & 33.3 & 22.2 \\
\hline Sub 6 & 2.8 & 20.0 & 33.3 \\
\hline Sub 7 & 0.9 & 25.0 & 25.0 \\
\hline
\end{tabular}

As evident in Table 7 the $T_{c}$ difference between the $T_{c}$ values from the three equations reduces when the catchments become smaller. Sub Catchment 7, the smallest among the seven sub catchments,

\subsection{Catchment Delineation}

It is common knowledge that when lumped parameter models are replaced by spatially distributed parameter models then the computations would be reaching better values and closer to the reality. Therefore in case of synthetic unit hydrograph derivation too, when a drainage area is divided into sub catchments and computations are carried out, it is expected 
that the values thus computed would provide realistic answers. Watershed streamflow amount and timing are mostly governed by the flow taking place over the land surface. The channel flows are often considered as less time consuming since the flow is concentrated into narrow sections and reaching the outlet at a comparatively less time than the overland flows. Accordingly in most hydrologic computations, flow through channel sections is usually ignored and only the processes within the rest of the watershed is utilised for assessments. The Case 2 of the present work is to simulate a similar situation where a modeller may opt to ignore the channel length from the exit of a particular sub watershed up to the main outlet of the drainage area. The case 3 takes into full account of both the overland flow and the channel flow components up to the main drainage outlet. The Case 1 is a typical lumped modelling approach. From engineering basics, it is clear that Case 3 would be the most appropriate approach and that the Case 1 would be the most simple and quick approach. The attempt of the present work was to capture the change in the values of peakflow and time to peak, when a modeller opts to either lump the parameters, or carryout a spatially distributed sub catchment approach or ignore the stream effects out side of the sub watersheds.

Table 8 shows the variation of Peakflows and Time to Peak in Case 2 and 3 with respect to those of Case 1.

Table 8 - Percentage Variation of Peakflows and Time to Peak in Case 2 and 3 with respect to those of Case 1.

\begin{tabular}{|c|c|c|c|c|c|}
\hline \multirow{2}{*}{ 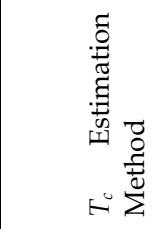 } & \multirow[b]{2}{*}{ 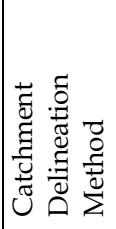 } & \multicolumn{3}{|c|}{ Peakflow } & \multirow[b]{2}{*}{ 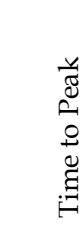 } \\
\hline & & $\frac{\check{a}}{\frac{0}{\omega}}$ & 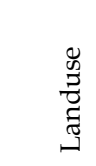 & 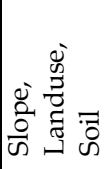 & \\
\hline \multirow{2}{*}{$\begin{array}{l}\text { ID } \\
\text { Guidelines }\end{array}$} & Case 2 & 32.97 & 32.84 & 32.65 & -40.00 \\
\hline & Case 3 & 4.40 & 4.48 & 4.08 & -18.84 \\
\hline \multirow{2}{*}{$\begin{array}{l}\text { Kirpich } \\
\text { Equation }\end{array}$} & Case 2 & 49.62 & 49.48 & 49.29 & -48.45 \\
\hline & Case 3 & 11.07 & 10.94 & 10.71 & -25.77 \\
\hline \multirow{2}{*}{$\begin{array}{l}\text { B-W } \\
\text { Formula }\end{array}$} & Case 2 & 32.87 & 32.38 & 32.89 & -43.90 \\
\hline & Case 3 & -0.70 & -0.95 & 0.00 & -14.03 \\
\hline
\end{tabular}

In the scale of the present case study watersheds, this work clearly indicates that there is a significant benefit both in the design of structures and planning flood warning, when a modeller opts to perform the synthetic unit hydrograph computations in a spatially distributed manner. It is also important to recognise that if the time taken for water to flow up to main catchment outlet from each sub catchment outlet is ignored, then there would be very high differences in Peak Discharge and Time to Peak, even for catchments of the magnitude selected for the present work.

\section{Conclusions and Recommendations}

- Unit hydrograph Derivation using the Rational method would yield a lesser peak flow value and a higher time to peak when spatially distributed approach using sub catchments is used instead of a lumped single catchment

- The guideline used for determination of Runoff coefficients plays very important role in Rational Method and it showed considerable variation of the results in Welipenna River Basin.

- The time of concentration estimation method is also important when the catchments become larger.

- In the Welipenna River Basin the Lumped Parameter method of deriving Unit Hydrograph taking Runoff Coefficient from Guideline 3 and with $T_{c}$ from ID Guidelines, resulted in a $Q_{p}$ estimate of $0.49 \mathrm{~m}^{3} / \mathrm{s}$, while the peakflow estimate computed with the distributed parameter method using sub catchments was $0.51 \mathrm{~m} 3 / \mathrm{s}$.

\section{References}

1. Ponrajah, A.J.P, Design of Irrigation Headworks for Small Catchments, 1st Ed. Irrigation Department, Colombo, 1984.

2. Wijesekra, N.T.S., "A Comparison of Peak Flow Estimates for Small Ungauged Urban Watersheds", Transactions, Annual Sessions of the IESL, Institution of Engineers, Sri Lanka, October 2000.

3. Batuwitage, L.P, Manchanayake, P., Wickramasuriya, S.S, "Comparative Study of Some Design Flood Estimation Methods for Sri Lanka", Engineer, The Journal of Institution of Engineers of Sri Lanka, Vol: XIV, No. 03, September 1986.

4. Ponrajah, 1988, Technical Guidelines for Irrigation Works, 1st Ed. Irrigation Department, Colombo, 1988. 
5. Chow, Ven Te, Maidment, David R., Mays, Larry W., Applied Hydrology,. Mc Grow Hill, 1988.

6. Maidment, David R., Applied Hydrology, Mc Grow Hill, Inc, 1993.

7. Institution of Engineers, Australia, Australian Rainfall and Runoff, 1977.

8. General Soil Map of Sri Lanka, National Atlas of Sri Lanka, Survey Department of Sri Lanka, 1988. 